Article

\title{
An Analysis of Game Design Elements Used in Digital Game-Based Language Learning
}

\author{
Terence Govender* (D) and Joan Arnedo-Moreno \\ Estudis d'Informàtica, Multimèdia i Telecomunicacions, Universitat Oberta de Catalunya, 08035 Barcelona, Spain; \\ jarnedo@uoc.edu \\ * Correspondence: tgovender@uoc.edu; Tel.: +27-082-662-6830
}

Citation: Govender, T.;

Arnedo-Moreno, J. An Analysis of

Game Design Elements Used in

Digital Game-Based Language

Learning. Sustainability 2021, 13, 6679.

https://doi.org/10.3390/su13126679

Academic Editors: Nuria Medina

Medina and Francisco Luis

Gutiérrez Vela

Received: 7 May 2021

Accepted: 1 June 2021

Published: 11 June 2021

Publisher's Note: MDPI stays neutral with regard to jurisdictional claims in published maps and institutional affiliations.

Copyright: (c) 2021 by the authors. Licensee MDPI, Basel, Switzerland. This article is an open access article distributed under the terms and conditions of the Creative Commons Attribution (CC BY) license (https:/ / creativecommons.org/licenses/by/ $4.0 /)$.

\begin{abstract}
Considerable changes have occurred in language learning with the introduction of gameful approaches in the classroom and the increase in the popularity of language applications like Duolingo. A review of existing studies on such approaches to language learning shows that gamification tends to be the most popular approach. However, this popularity has been achieved at the expense of other gameful approaches, such as the use of digital games. To gain a clearer picture of the developments and gaps in the digital game-based learning research, this paper examines and categorizes observations about game elements used in published papers $(n=114)$ where serious and digital games were tested in language education settings. Game element analysis reveals that (1) the most frequently occurring elements in digital game-based language learning (DGBLL) are feedback, theme, points, narrative, and levels; (2) even though there was significant variance in the number of elements observed in DGBLL, both the bespoke and off-the-shelf games show similar high-frequency elements; (3) DGBLL has been applied to vocabulary acquisition and retention in many cases, but lacks implementation and testing in input and output language skills; (4) although there is some consensus on the most frequent elements, the design patterns of common elements according to age group and target language skill show considerable variance; (5) more research is needed on less common design elements that have shown promise in encouraging language acquisition. The synthesis of information from the collected papers contributes to knowledge regarding DGBLL application design and will help formulate guidelines and detect efficacy patterns as the field continues to grow.
\end{abstract}

Keywords: gamifying language education; digital game-based learning; serious games; critical review

\section{Introduction}

Language education is a fundamental part of society. Learning a language requires large amounts of both time and effort, but there is a myriad of reasons for pursuing such an undertaking. Some reasons are more casual, such as taking a short vacation overseas, whereas others are more serious, such as working or studying in a foreign country. Therefore, people of any age and background may be interested in learning or might be required to learn an additional language. With the world becoming more accessible on several fronts, English has emerged as a lingua franca for many to communicate with friends in different countries via the Internet, to increase tourism, or to conduct international business. Additionally, highly ranked universities in western countries attract many international students due to their diverse range of subject matters created and presented by renowned professors. Although this can incentivize or coerce the learning of a new language, many language students do not have enough language exposure or practice to establish a new lexicon. Furthermore, there are cases where language is purely studied for testing rather than its communicative function or cultural richness. Learning a language for its instrumental value rather than enjoyment can create barriers such as a lack of engagement and motivation, leading to students not wanting to practice. 
One issue that arises from lack of practice is that language knowledge can quickly deteriorate when used infrequently [1]; this is especially true for learners who have no exposure to the target language in their daily lives. Additionally, learners who find the language challenging to learn, or do not feel that the target language is beneficial, tend to become demotivated. Since thorough practice and immersive, meaningful experiences are critical factors for acquiring language, the unique nature of language education and increasing demand have created a need for effective language teaching methods. Pedagogical approaches such as the communicative method (which focuses on interaction) have been shown to help with language learning but greater learner motivation and engagement have been found through gameful approach incorporation [2]. Consequently, there have been considerable advances in approaches to presenting language lessons, focusing on using interdisciplinary knowledge to create stimulating environments.

Given the issues surrounding language acquisition, gameful approaches have effectively overcome several learning barriers. Three distinct gameful approaches have emerged in language education. First and foremost, gamification, or the use of game design elements to encourage engagement, increased in popularity around 2011 when it entered Gartner's Hype Cycle (https:/ / www.gartner.com/en/research/methodologies/gartner-hype-cycle (accessed on 12 April 2021)). Gartner's Hype Cycle is a research methodology accompanied by a visual representation of how new and emerging technologies mature and evolve over time, especially when considering their application and success. Gamification's popularity in language learning is evidenced by its frequency in the rise in mobile language-learning applications such as Duolingo [3]. Another approach is using serious games. Serious games are games or game technology used for purposes beyond entertainment such as training, health, or education [4]. Finally, although not a new concept, game-based learning is a topic that has received a fair amount of attention over the past few years. Game-based language learning has various forms, such as role-playing games for communication practice (e.g., Werewolf [5]) or board games for solidifying grammar (e.g., Apples to Apples [6]). With recent implementations moving to digital platforms (e.g., practicing target language by debating in Second Life $[7,8]$ ), research has found a plethora of benefits in addition to improvements in learning performance, such as increased motivation to learn through meaningful learning experiences [9] and creating autotelic-conducive environments [10].

It may seem counterproductive to play digital games, purely designed just for fun, for the purpose of learning. However, there is increasing evidence to suggest that users who play games in their non-native language can actively acquire a target language to progress in the game [11] or talk to other players [12]. Additionally, many games have external resources such as wiki sites that contain information valuable for the players. Exposure to digital games and these external environments surrounding games have been found to improve target language acquisition $[13,14]$ to the extent that gamers, on average, tend to have more target language vocabulary than non-gamers [15]. Gaming is no longer a niche market. The popularity of games is evident, with $75 \%$ of American homes having at least one gamer Entertainment Software Association (https:/ / www.theesa.com/ resource/2020-essential-facts / (accessed on 30 March 2021)) according to the Entertainment Software Association's 2020 statistics. Given the potential impact of digital game-based learning on language acquisition, it is essential to collate the data regarding successful designs to advance language education implementation strategies. Furthermore, given the essential nature of communication, deciphering the mechanisms that contribute to effective language acquisition will be crucial to overcoming future challenges as the need for language education is ever-present.

The contribution of this paper is filling the dearth of knowledge regarding how to design digital game-based language learning (DGBLL). This paper aims to break down the games into their design features to find commonalities amongst DGBLL applications. The data presented here will be instrumental in suggesting design features for future applications employing this learning method. This knowledge was achieved by systematically searching the literature for design features that have been used frequently in DGBLL 
applications, and categorizing these features using an existing framework. The following questions were used to guide the study:

- RQ1: What are the most frequently used game design elements in DGBLL?

- RQ2: What are the differences in game elements between bespoke games, off-the-shelf games, games for entertainment, and games for education?

- RQ3: Are there differences between bespoke and off-the-shelf games regarding their impact on observed outcomes within a specific age group?

- RQ4: Are there differences between the minor design elements regarding language skills?

- $\quad$ RQ5: What are some lesser-used game design elements in DGBLL applications that have shown potential?

This paper is structured as follows: Section 2 provides background information and describes research related to this study; Section 3 explains the methods used to collect, filter, and code the papers used in this review; Section 4 presents the findings from the papers that were analyzed and discusses the patterns found in DGBLL applications according to the research questions; Section 5 ends the paper with a conclusion and topics that require further research.

\section{Background and Related Research}

This section briefly examines the concepts and previous research to provide context for the topics discussed in this paper.

\subsection{Distinction between Games for Entertainment, Serious Games, and Gamification}

Game-based learning involves using games to execute learning content. This learning approach is employed in a variety of forms, for example, using analogue games (such as board games, card games, or scavenger hunts) or digital games. Gamification, however, uses game elements as a method to augment lessons for engagement and motivation. Although these two concepts are distinct and separate, they share the same goal of engaging learners using the same game design features.

The focus of this paper is on digital games used as gameful approaches to language learning. This approach is a stark contrast to gamification, an approach that uses game design elements in non-game contexts [16]. For example, a digital game-based approach would use a game such as Monkey Island [17] or Deponia [18] to promote contextual learning. Both of these games use interesting dialogue and puzzles to create an entertaining interactive story. The players may experience situations that are not commonly encountered, such as the cannibals on Monkey Island, and gain an understanding of the topic when in context via the dialogue and visuals. In contrast, gamification introduces points and badges to a traditional classroom to create a game-like environment. Another distinction is that digital game-based learning requires technology for implementation, whereas gamification can be added through both analogue and digital means.

Distinguishing serious games from digital game-based learning can be challenging because their concepts are not easily discernible. Susi illustrated a certain complexity to finding a definition for serious games [4]. Even Deterding [16] acknowledged that multiple factors contribute to the categorization of serious games and games for entertainment. The report by Susi summarized a few points of comparison between serious games and video games. Serious games focus on the problem-solving aspect and learning components, whereas digital games aim at entertainment focus on providing a fun, rich experience for the players. The main differences exist in the execution of content. Serious games focus on providing the necessary learning material for users to be able to solve problems or work through simulated events. Since the learning content supports the activities, serious games are able to offer non-perfect environments that can simulate more realistic scenarios and communication [4]. In this way, users can be tested on how well they have assimilated the learning content through conscious decision making. In contrast, video games offer richer experiences and more direct interactions. Rich experiences can involve features 
such as epic boss battles, lore and narration, or customization (for example, esthetics or character statistics). Although users can learn how to master avatar movements or learn character-building for powerful avatars, these components form part of the experience rather than having educational value. For this study, any experiment or observation that uses a digital game (regardless of its original intent) as part of a gameful approach to language acquisition is grouped under the umbrella term DGBLL.

Using games for learning has been linked to encouraging engagement because of their characteristics [19]. Many studies have found that DGBLL can effectively reduce affective barriers such as anxiety and increase the willingness to communicate [20,21]. Therefore, games can guide users through autonomous, immersive learning experiences while adding a level of fun that is difficult to achieve with traditional lesson material. However, digital game-based learning research suffers from a considerable variance in methods, approaches, and frameworks, and a lack of empirical evidence supporting all of the facets of a game's design [22,23]. Therefore, creating definitive guidelines for the creation or use of DGBLL becomes more challenging.

\subsection{Previous Research}

Game-based learning has been the topic of many literature reviews over the years and for various reasons. General literature reviews on gameful approaches to education such as Boyle [24] and Dichev [25] revealed low percentages for language education studies (3.1\% and $8 \%$, respectively). Dichev also stated that our understanding of designing gameful environments in education is still lagging.

Only a few meta-analyses have focused on digital game-based learning, and even fewer focused on DGBLL in particular. Hung [26] explored the state of DGBLL in any language and summarized a large amount of data from 2007 to 2016. The literature review analyzed 50 papers and noted that massively multiplayer games were the most commonly used genre in DGBLL literature at the time. Hung also found that most researchers created bespoke applications for these studies, and university students were the most frequent target audience. This review focused on many aspects surrounding the use of DGBLL rather than the design of the applications.

A more recent review by $\mathrm{Xu}$ [27] filtered through results to analyze 59 research papers where English was the target language and examined DGBLL design. $\mathrm{Xu}$ found that vocabulary was the most prevalent language skill studied, and gameful elements lacked consistency amongst the digital games used. The design categorization used in this review was adapted from Shute [28], who well-categorized what the user should experience but did not identify the specific elements needed to accomplish these goals.

Both of the prior DGBLL meta-analyses lacked detailed game design elements. Therefore, it was necessary to explore the game design aspect more deeply since it was unclear which game elements are being included in these applications.

\section{Methods}

A thorough review of the current literature was conducted to better understand the frequent, specific game elements featured in DGBLL. This review used the EBSCO Discovery Service. The process is summarized in Figure 1. The list of databases that were accessed for information and the number of papers found are summarized in Table 1. 
Table 1. Summary of databases accessed during the literature search.

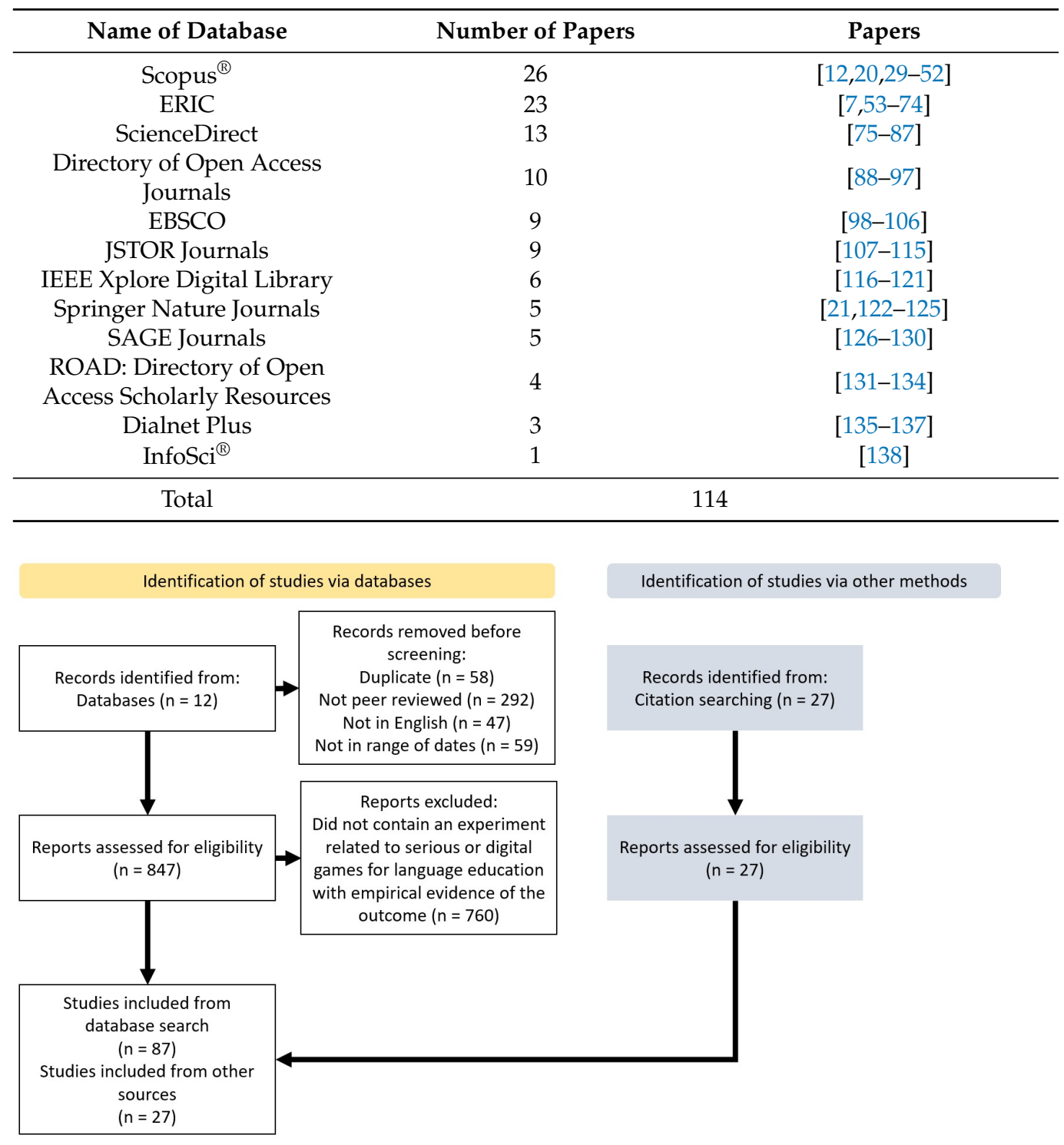

Figure 1. Search method and filtering process.

\subsection{Search Items and Criteria}

A search for "(serious game language) OR (digital game language) OR (game-based language)" written in English from 2010 to 2021 yielded 1303 results on 30 January 2021. Additional papers were found while reading through relevant literature. The following criteria were used to filter results for the appropriate studies to be included in the review:

1. Must be peer-reviewed (292 filtered out);

2. Must have been published between 2010 and 2021 inclusively (59 filtered out);

3. Must be written in English (47 filtered out);

4. Cannot be a duplicate (58 filtered out);

5. Must contain an experiment related to serious or digital games for language education with empirical evidence of the outcome (760 filtered out).

\subsection{Coding and Categorization}

To reduce redundancy with previously conducted research, the data extraction and coding focused on the game design elements using a framework that could identify specific features. Other game-based learning reviews used more general design models such as Shute [28] and ARCS [139]. For example, ARCS, which stands for attention, relevance, 
confidence, and satisfaction, is a detailed model and contains several design elements needed to create motivational environments. However, when DGBLL applications are divided into ARCS alone, we are left with a shallow idea of what elements are being implemented since they are categorized into four parts. With only four design categories, in-depth analysis is not possible for large-scale reviews since it is difficult to determine the individual game features that are being implemented to use the framework. Therefore, given the variety of features that can be found within one of these categories, only surfacelevel observations of patterns are possible using such a framework.

\subsubsection{Game Elements}

Since this analysis is heavily focused on the design elements found in DGBLL applications, it is important to understand what the elements are. They can be easily explained by their role within a game ecosystem as the properties and characteristics that create gameful affordances for users [140]. Simply, game elements are the building blocks that add features such as mechanics (the rules and procedures governing interactions with the game) or story (the sequence of events the user will experience) [141]. Thus, many game or gamification design frameworks are based on their categorization to facilitate structuring the creative process [142].

Among such frameworks, the one adopted for this study was Marczewski's Gamification Mechanics and Elements [143]. Marczewski's element framework is organized based on the user types found in the Gamification User Types Hexad Scale [144], which comprises categories and descriptions of the different personalities of users. The User Types Hexad separates elements according to preferences of users, namely, general users (this type of user is not counted in the Hexad since elements appeal to most users), socializers (elements appeal to users that want to communicate with others), free spirits (elements appeal to users that want fewer restrictions), achievers (elements appeal to users that want to complete goals), philanthropists (elements appeal to users that want to give to others), disruptors (elements appeal to users that want to change or disrupt game systems), and players (elements appeal to users that want to master a system).

Marczewski's game elements and the Hexad scale have been used in several validation studies [145-147], including observations in educational settings [148,149]. Although the User Types Hexad plays an important part in the design choices related to the elements, the focus of this paper is the elements themselves. The framework is extensive, composed of 52 elements. A summary describing the elements relevant to this study can be found in Appendix A Table A1. An in-depth description of all elements can be found in [143].

Although it was already mentioned that gamification and games are separate entities, it is also true that gamification is based on game characteristics [16]. Therefore, gamification elements and game elements can be considered equivalent from an engagement design perspective. Using Marczewski's element framework, the analysis is more meticulous than other categorization methods used in previous reviews. The framework offers a more fine-grained analysis due to the number of elements, which is considered more useful than ARCS. Furthermore, since the element framework is also supported by the User Type Hexad, the data can be processed further if necessary. Therefore, Marczewski's framework successfully provided more insight into the design of DGBLL implementations.

Although Marczewski's approach to classifying elements and mechanics has been well-studied in the scientific literature [142], the psychological aspects are difficult to predict based on individual personality differences. A good example is determining if the element "meaning or purpose" is felt during an experiment. Chou [150] also tried to explain this intrinsic motivator by proposing that it drives certain people to complete tasks. However, a psychological aspect is not an in-game feature that can be seen or clicked on demand. Several other elements can contribute to a player experiencing meaning or purpose in a game, such as the narrative (assuming the language learner can understand the story) or collaboration (working together to help the less fortunate). Even if there are multiple 
contributing factors, a player might not experience a specific psychological state. For this reason, the following psychological game design features were excluded:

- Loss aversion (which can be caused by consequences);

- Meaning/purpose (which can be related to the narrative/story);

- $\quad$ Flow (which can be related to challenge and uncertainty);

- Social pressure (which can be related to the multifaceted nature of an individual)

The investment feature was discarded because language education inherently requires considerable time and dedication. Since the definition proposed by Marczewski includes time as a factor, any game used for education would include investment by default.

Additionally, there were instances where the experiment setup either added or subtracted game elements. In these cases, the game was given priority. For example, although Marta [97] used a single-player game to test dyads and Yamazaki [68] assigned participants quests not included in the game, team/guild and questing, respectively, were not counted as elements.

The game elements were also separated according to their frequency. Major elements were found in 50\% or more of the DGBLL applications in a given category. Minor elements were the top three (where possible) highest-frequency elements, occurring between $25 \%$ (inclusive) and $50 \%$ of the time. This separation was necessary to distinguish implementations due to the similarity in high-frequency game elements.

\subsubsection{Off-the-Shelf and Bespoke Games}

For simplicity, games were divided into four categories: bespoke games, commercial off-the-shelf (COTS), games for education, and games for entertainment. COTS refers to any ready-made application that was not explicitly created for the experiment. Therefore, a COTS game is a game that was available to the researchers without needing to create anything completely new, this included modifying existing games. Bespoke games, in contrast, are applications that are not available commercially. Bespoke games include games developed by or for the researcher or research team. The third category contains games created for education. Educational games include serious games and other games where the main purpose of the game is to learn something. This category includes games from both the COTS and bespoke categories. The final category is games that were created for entertainment. These are the games that inspire many of the features found in the bespoke and educational games. Predictably, all of the games for entertainment are also found in the COTS category. Games such as Minecraft [151] (especially the education edition) show that education and entertainment can overlap. It achieves this by creating an environment where users are provided the opportunity to learn, create, and explore while only being limited by their imagination. In Table 2 alone, duplicate games (games that appeared in more than one study) are only coded once.

\subsubsection{Age Groups}

There is a large variety of age classifications worldwide, especially for schools. Therefore, for clarity, age groups were divided into preschool, primary school, secondary school, and tertiary school and adults. Preschool ages range from 2 to 6 years, primary school from 6 to 13 years, and secondary school ranged from 13 to 18 years and not enrolled in tertiary education. Tertiary education and adults were combined because only one paper mentioned adult participants that were not university students. Additionally, a few of the studies combined university students and faculty members in the observations. 
Table 2. Summary of highest-frequency game design elements according to game type.

\begin{tabular}{|c|c|c|}
\hline Category & Name of Element & Frequency \\
\hline $\begin{array}{l}\text { Bespoke } \\
\text { games } \\
(n=52)\end{array}$ & $\begin{array}{l}\text { 1. Progress / feedback } \\
\text { 2. Theme } \\
\text { 3. Points/experience points (XP) } \\
\text { 4. Narrative/story } \\
\text { 5. Signposting }\end{array}$ & $\begin{array}{l}98.08 \% \\
73.08 \% \\
44.23 \% \\
40.38 \% \\
36.54 \%\end{array}$ \\
\hline $\begin{array}{l}\text { COTS } \\
\text { games } \\
(n=48)\end{array}$ & $\begin{array}{l}\text { 1. Progress/feedback } \\
\text { 2. Theme } \\
\text { 3. Points/experience points (XP) } \\
\text { 4. Levels/progression } \\
\text { 5. Time Pressure }\end{array}$ & $\begin{array}{c}93.75 \% \\
66.67 \% \\
60.47 \% \\
50 \% \\
39.58 \%\end{array}$ \\
\hline $\begin{array}{l}\text { Games } \\
\text { for edu- } \\
\text { cation } \\
(n=88)\end{array}$ & $\begin{array}{l}\text { 1. Progress / feedback } \\
\text { 2. Theme } \\
\text { 3. Points/experience points (XP) } \\
\text { 4. Narrative/story } \\
\text { 5. Time Pressure }\end{array}$ & $\begin{array}{l}97.73 \% \\
65.91 \% \\
48.86 \% \\
34.09 \% \\
32.94 \%\end{array}$ \\
\hline $\begin{array}{l}\text { Games } \\
\text { for enter- } \\
\text { tainment } \\
(n=12)\end{array}$ & $\begin{array}{l}\text { 1. Theme } \\
\text { 2. Progress/feedback } \\
\text { 2. Levels/progression } \\
\text { 3. Onboarding/tutorials } \\
\text { 3. Narrative/story } \\
\text { 3. Exploration } \\
\text { 3. Points/experience points (XP) } \\
\text { 3. Customization }\end{array}$ & $\begin{array}{c}100 \% \\
83.33 \% \\
83.33 \% \\
75 \% \\
75 \% \\
75 \% \\
75 \% \\
75 \%\end{array}$ \\
\hline $\begin{array}{l}\text { Overall } \\
(n=100)\end{array}$ & $\begin{array}{l}\text { 1. Progress/feedback } \\
\text { 2. Theme } \\
\text { 3. Points/experience points (XP) } \\
\text { 4. Narrative/story } \\
\text { 5. Levels/progression }\end{array}$ & $\begin{array}{l}96 \% \\
70 \% \\
52 \% \\
39 \% \\
36 \%\end{array}$ \\
\hline
\end{tabular}

\subsubsection{Language Learning Outcomes}

Since the purpose of using DGBLL is to create engaging teaching environments, psychological factors such as participants' willingness to communicate and motivation effects were not analyzed. This study was aimed at the design elements used to improve the participants' skills, for example, the language skills that were tested to differentiate or evaluate the outcome of the DGBLL application as a teaching tool. The language skill categorization was adapted from Hung's review [26]. The language skills needed enough data to show patterns. For this reason, reading and listening were categorized into input skills. Likewise, writing and speaking were combined into a category called output skills. The other categories were communication, vocabulary, grammar, and multiple language skills. The following list details more information regarding how each skill was identified:

- Reading involved comprehension tasks from text;

- $\quad$ Listening involved comprehension tasks from audio;

- $\quad$ Speaking involved speeches and phonetics (pronunciation and articulation);

- Writing involved essays, creative writing, and written word formation;

- Vocabulary involved lexicon development and retention, including semantics;

- Communication involved contextual or non-contextual interactions.

\section{Results and Discussion}

Games can be valuable tools for educators to create interactive content for language lessons. The search results are summarized in this section to provide some information regarding implementation strategies that have been used. Additionally, the discussion includes game design patterns found in the literature to suggest effective design practices. Surprisingly, identifying design features and the benefit of using specific elements were pri- 
marily found in bespoke game papers, especially studies that detailed the artefact's creation. For example, Ongoro described the steps taken, from literature review to prototyping [40]. Additionally, Ogoro included the justification of using points and feedback due to their success in other studies. Similarly, Yang designed a bespoke game and provided a detailed literature review before creating an artefact that evaluated the badge element [127]. Yang's literature review justified the reasons for and necessity of testing this element's influence. In contrast with the design details found in bespoke papers, games for education were generally promoted for encouraging motivation based on previous works. For example, Azman [92] justified using a COTS game for entertainment because the genre of the game provides evidence of positive outcomes, and it has attractive features that are known for motivating players. The elements that appealed to the researcher were not stated directly but were justified by its popularity and track record. Bespoke game papers tended to more closely examine the individual components, whereas COTS game papers focused on the prior results of the games.

\subsection{What Are the Most Frequently Used Game Design Elements in DGBLL?}

The first step in identifying patterns in game design is to examine an overview of the elements used. Table 2 shows the summarized frequency information of the top five (eight for entertainment games due to duplicate frequencies) game design elements according to Marczewski's framework. The table is divided into the four categories mentioned in Section 3.2.2. The data in this table provide an idea of how games for specific purposes compare and offer a foundation for further analysis. The list of games can be found in Appendix A Table A2 (bespoke game list) and Table A3 (COTS game list).

From the table, games for entertainment were fewer and resulted in duplicate frequencies. Consequently, entertainment games contained more varied elements than the other categories. Overall, the most common game element was a feedback system, which was featured in $96 \%$ of the games. Giving language students feedback is an essential part of language acquisition and has shown positive results in computer-assisted learning [152]. Furthermore, even mobile language learning applications designed for autonomous learning also place significant importance on having a feedback element [3] to simulate a teacher providing correct responses or fixing errors. Various types of feedback are generally broken down into explicit (e.g., explaining what is wrong and showing the correction) and implicit (e.g., indicating that an utterance is incorrect by eliciting a new answer) feedback. Cornillie [37] observed that explicit corrective feedback has more impact on language learning than implicit feedback. The test involved a digital game created to compare learners' perceptions when exposed to different feedback types. In contrast with feedback in games for entertainment, when creating simulations, implicit feedback can help to encourage the natural flow of a conversation without stopping to explain language rules, such as interacting with Hazel's virtual agents [89]. A variety of feedback systems were found among the papers. For example, implementations of feedback ranged from point systems, such as a visible score for answering questions in Smith's [76] eBook game, to health systems, such as Economou's [105] action game for British Sign Language, where the player loses hitpoints for incorrect responses.

Theme and narrative, as elements, can be found together, such as in Hamari [153], but the theme is often ignored as an individual element. However, there is a distinction between these two elements, and it is essential to note the difference since theme can be found in more educational applications than in stories. The theme includes settings or characters that are consistent within a game. Therefore, a theme can be included for user experience purposes. To illustrate, Duolingo does not contain a story, but the iconic owl is a consistent fantasy character that encourages the user. The setting of Spaceteam ESL [71] is space-themed, but there is no narrative mentioned as a feature. Although a theme can stand alone, none of the papers with a narrative or story lacked a theme. Since storytelling is a prominent feature in game design [154], an interesting finding was that nearly $60 \%$ of the bespoke and overall chosen games lacked an identifiable story. 
The third most frequent element was points or experience points. Points are related to scores, and experience points are related to user progression. The user gains experience by completing a task, battle, or challenge and being rewarded or validated for the outcome, usually through an avatar. A scoring system was commonly found amongst the educational games, and experience point systems were more frequently found in games for entertainment.

Levels and progression are related to increasing difficulty within the learning content. This adaptive system can be displayed as the user increasing in skill (thus needing additional challenge), the user completing stages and progressing through content of increasing difficulty, or a combination of the two. This element was found frequently in games for entertainment $(75 \%)$, regularly in COTS games $(50 \%)$, but only $29.55 \%$ of educational games and $28.57 \%$ of the bespoke games. An example of this system is found in My-Pet-Store [115] where the participants can progress through six levels of lesson material.

4.2. What Are the Differences in Game Elements between Bespoke Games, Off-the-Shelf Games, Games for Education, and Games for Entertainment?

The answer to RQ1 provided surface-level information regarding the differences between the elements in the four game categories. However, these games were the primary educational tools considered in this study. Therefore, further analysis was necessary to form a clear picture of the characteristics of each group and to identify differences and similarities. Figure 2 details the number of game elements found in the analyzed papers, specifically displaying the median, interquartile range, and outliers among the different game categories.

The figure shows the large gap in game element quantity between games constructed for education versus entertainment. These findings are similar to those of $\mathrm{Xu}$ [27] in that the DGBLL applications are inconsistent in their quantity of game characteristics. Interestingly, bespoke games and games for education categories were similar in element quantity. Although it is difficult to see on the box plot due to the minute difference, COTS educational games used fewer game elements, on average, than the bespoke games. The mean value of game elements in bespoke games was 5.56, and the mean value of COTS educational games was 5.11 .

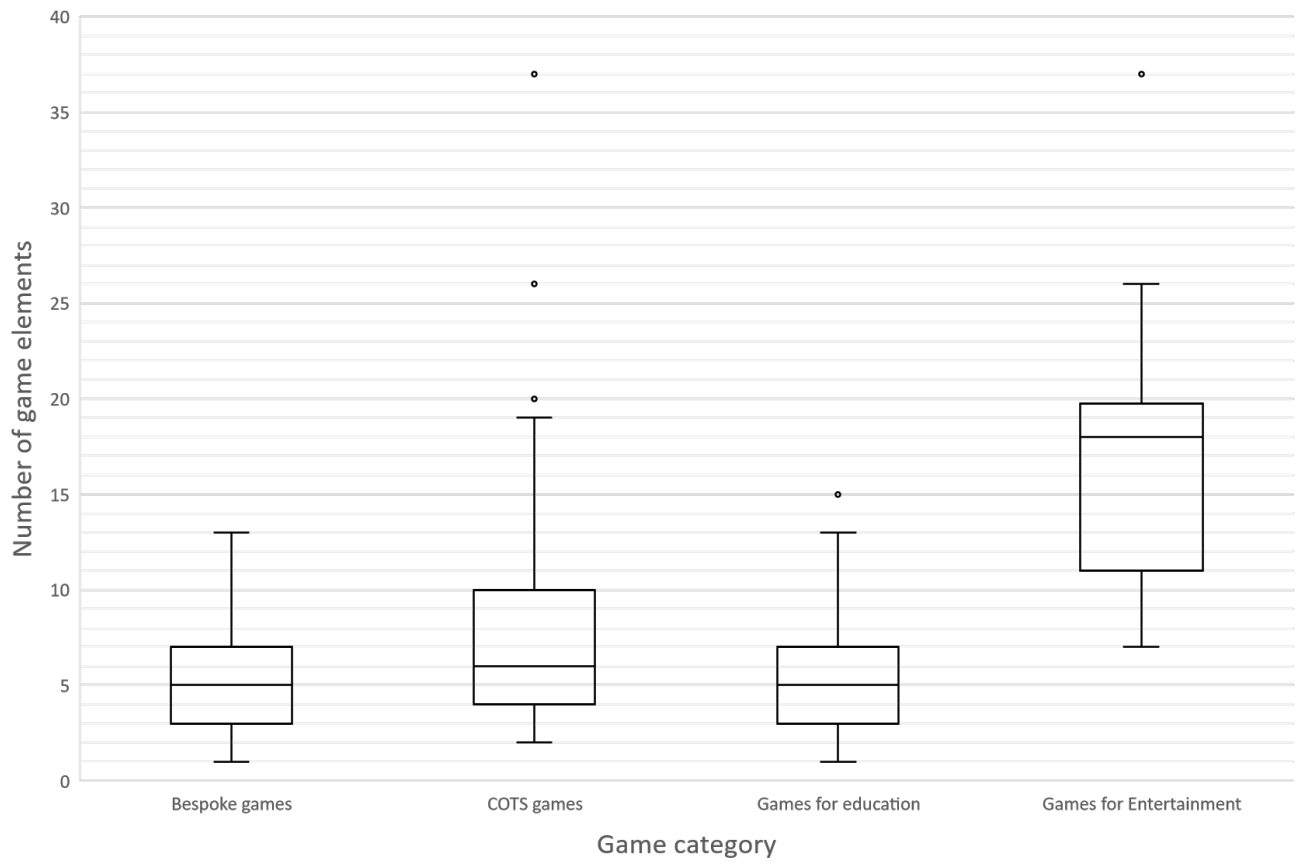

Figure 2. Box plot showing differences among game categories. 


\subsection{Are There Differences between Bespoke and Off-the-Shelf Games Regarding Their Impact on Observed Outcomes within a Specific Age Group?}

Understandably, games intended for more mature audiences would not be used for younger users. Maturity, in this case, can refer to properties such as physical ability (motor skills or endurance) or cognitive ability (concrete or abstract thinking). Information regarding design patterns for specific ages can be beneficial in forming frameworks for compelling games.

Table 3 summarizes information regarding age groups and learning impact. In this table, the age groups are listed according to the coding in Section 3. This column is followed by frequent elements found in the gameful approaches used in the papers. Frequent elements in this table are defined as elements occurring in 50\% or more of the DGBLL applications. Next, bespoke and COTS games are listed as percentages with the number of games for entertainment found in brackets. Finally, the studies' outcomes are listed, showing what type of outcome was tested. This is followed by the findings categorized as positive (Pos), negative (Neg), inconclusive or no significant findings (In/NS), and mixed (Mix). Finally, the number of papers per age group is presented in the last column. One paper [99] was excluded because the age group was not indicated, being why the final column total is 113 instead of 114 . Additionally, since this table uses data extracted from each paper, game duplicates are present.

Unsurprisingly, feedback and theme are heavily featured throughout the age groups. Three differences were found in the frequent elements present among the age groups. First, the points element was not featured as a frequent element in preschool DGBLL. Second, the theme element was not commonly found in mixed-age-group studies; however, levels were more frequent. Finally, secondary school papers contained the highest concentration of game elements with an average of 11 game elements.

Primary school was the only age group that used more bespoke applications. Secondary school studies featured the highest percentage of games for entertainment (37.5\%), while preschool studies contained no games for entertainment. In terms of outcome, the papers showed that DGBLL was positive in general $(79.65 \%)$. The most positive ratio was found in secondary school studies. These studies also included the most games for entertainment such as L.A. Noire $[79,155]$ and The Sims $[102,156]$. These games were aimed at vocabulary and had a high concentration of game elements but were implemented for different reasons. The Sims was chosen because it met all the criteria for being a good game, and L.A. Noire was chosen for its interactive story. The games operate and are experienced in entirely different manners but are used for the same purpose: to provide a meaningful environment for vocabulary acquisition. This comparison is only one example of the diversity of implementations within the same age group and targeted language skill. Overall, the number of papers targeting secondary school was relatively low, with only 8 of the total 113 papers that mentioned participant age groups.

Table 3 also shows a significant difference in the number of papers among targeted age groups; more than $50 \%$ of the papers contained university and adult participants $(n=61)$ (e.g., $[70,76,103])$. Hung [26] reported a similar finding with around $44 \%$ of the papers in the study involving university students. The next largest age group was primary school participants $(n=29)$ that were found in around $25 \%$ of the papers. The sizeable disproportion in age groups complicates the identification of prediction patterns for game elements. Therefore, more research on this gameful approach is needed in preschool and secondary school settings. The disproportion may be due to less strict ethical procedures with adults, adults having more technical skills, or university faculty having the ability to manipulate their curriculum [25]. 
Table 3. Summary of frequent elements and impact of gameful approach according to age group.

\begin{tabular}{|c|c|c|c|c|c|c|c|c|c|}
\hline \multirow{2}{*}{$\begin{array}{c}\text { Age } \\
\text { Group }\end{array}$} & \multirow{2}{*}{$\begin{array}{l}\text { Frequent } \\
\text { Elements }\end{array}$} & \multicolumn{2}{|c|}{$\%$ of Games } & \multicolumn{6}{|c|}{ Number of Observed Outcomes } \\
\hline & & Bespoke & COTS & Outcomes tested & Pos & Neg & In/NS & Mix & Total \\
\hline Preschool & $\begin{array}{c}\text { Major: } \\
\text { Feedback and } \\
\text { theme } \\
\text { Minor: Time } \\
\text { pressure, points }\end{array}$ & $37.5 \%$ & $62.5 \%$ & $\begin{array}{c}\text { Perception, } \\
\text { evaluation of } \\
\text { system, language } \\
\text { skill performance, } \\
\text { contextual learning }\end{array}$ & 6 & 0 & 2 & 0 & 8 \\
\hline $\begin{array}{c}\text { Primary } \\
\text { school }\end{array}$ & $\begin{array}{l}\text { Major: } \\
\text { Feedback, } \\
\text { theme and } \\
\text { points } \\
\\
\text { Minor: } \\
\text { Signposting, } \\
\text { fixed rewards } \\
\text { and levels }\end{array}$ & $58.62 \%$ & $41.38 \%(1)$ & $\begin{array}{l}\text { Perception, anxiety, } \\
\text { motivation, } \\
\text { evaluation of } \\
\text { system, framework } \\
\text { or technology, } \\
\text { language skill } \\
\text { performance, } \\
\text { contextual learning, } \\
\text { willingness to } \\
\text { communicate }\end{array}$ & 22 & 1 & 3 & 3 & 29 \\
\hline $\begin{array}{c}\text { Secondary } \\
\text { school }\end{array}$ & $\begin{array}{c}\text { Major: } \\
\text { Feedback, } \\
\text { theme, story, } \\
\text { signposting, } \\
\text { points and time } \\
\text { pressure }\end{array}$ & $33.33 \%$ & $66.67 \%(3)$ & $\begin{array}{l}\text { Perception, anxiety, } \\
\text { attitude, } \\
\text { engagement, } \\
\text { motivation, } \\
\text { evaluation of } \\
\text { system, language } \\
\text { skill performance, } \\
\text { cognitive } \\
\text { complexity }\end{array}$ & 7 & 0 & 0 & 1 & 8 \\
\hline $\begin{array}{c}\text { Tertiary } \\
\text { and adult }\end{array}$ & $\begin{array}{l}\text { Minor: Time } \\
\text { pressure, } \\
\text { narrative, levels }\end{array}$ & $40 \%$ & $60 \%(16)$ & $\begin{array}{l}\text { Perception, anxiety, } \\
\text { behavior, attitude, } \\
\text { motivation, } \\
\text { evaluation of } \\
\text { system, technology, } \\
\text { framework and } \\
\text { educational } \\
\text { strategy/approach, } \\
\text { language skill } \\
\text { performance, } \\
\text { cognitive } \\
\text { complexity, } \\
\text { contextual learning, } \\
\text { willingness to } \\
\text { communicate, } \\
\text { creativity }\end{array}$ & 50 & 0 & 3 & 8 & 61 \\
\hline
\end{tabular}


Table 3. Cont.

\begin{tabular}{|c|c|c|c|c|c|c|c|c|c|}
\hline \multirow{2}{*}{$\begin{array}{c}\text { Age } \\
\text { Group }\end{array}$} & \multirow{2}{*}{$\begin{array}{l}\text { Frequent } \\
\text { Elements }\end{array}$} & \multicolumn{2}{|c|}{$\%$ of Games } & \multicolumn{6}{|c|}{ Number of Observed Outcomes } \\
\hline & & Bespoke & COTS & Outcomes tested & Pos & Neg & In/NS & Mix & Total \\
\hline \multirow[t]{2}{*}{ Mixed } & $\begin{array}{c}\text { Major: } \\
\text { Feedback, } \\
\text { levels, points }\end{array}$ & $40 \%$ & $60 \%(1)$ & $\begin{array}{l}\text { Perception, } \\
\text { motivation, } \\
\text { evaluation of } \\
\text { system and } \\
\text { technology, } \\
\text { language skill } \\
\text { performance }\end{array}$ & 5 & 0 & 1 & 1 & 7 \\
\hline & $\begin{array}{c}\text { Minor: Theme, } \\
\text { narrative }\end{array}$ & & & & & & & & \\
\hline Total & & & & & 90 & 1 & 9 & 13 & 113 \\
\hline
\end{tabular}

\subsection{Are There Differences between the Minor Design Elements Regarding Language Skills?}

Language skills are the core of DGBLL and need to be thoroughly investigated. Since highly frequent (major) elements found during the analyses tend to be similar, it is important to look at the nuances within games aimed at specific language skills. These minor details can help us understand more about the role of game elements in DGBLL by shedding light on how they impact specific areas of acquisition.

Table 4 summarizes language skill implementation in the analyzed papers. For this summary, the number of games was analyzed instead of the number of papers. Considering that some authors such as Zhonggen [82] and Karaaslan [67] used multiple games, the total number of games was higher than the number of papers $(n=119)$. Additionally, three papers were omitted because they did not explicitly test or observe language skills or performed tests that were not fully explained.

Table 4. Summary of minor elements according to language skills.

\begin{tabular}{ccc}
\hline Language Skill & Minor Elements & Number of Games (COTS) \\
\hline Input & $\begin{array}{c}\text { On-boarding, narrative, time } \\
\text { pressure, consequences, } \\
\text { customization, and levels }\end{array}$ & $4(1)$ \\
\hline Output & $\begin{array}{c}\text { Fixed reward schedule, quests, } \\
\text { levels, and badges }\end{array}$ & $13(6)$ \\
\hline Vocabulary & $\begin{array}{c}\text { Time pressure, leaderboards, } \\
\text { and levels }\end{array}$ & $51(28)$ \\
\hline Grammar & $\begin{array}{c}\text { Signposting, learning, levels, } \\
\text { anonymity, and leaderboards }\end{array}$ & $25(14)$ \\
\hline Communication & $\begin{array}{c}\text { Social discovery, anonymity, } \\
\text { signposting, fixed reward } \\
\text { schedule, sharing knowledge, } \\
\text { and anarchy }\end{array}$ & $20(14)$ \\
\hline Total & & $\begin{array}{c}\text { Time pressure, teams, social } \\
\text { networking, narrative, } \\
\text { exploration, and levels }\end{array}$ \\
\hline
\end{tabular}

The summary echoes a similar result to $\mathrm{Xu}$ [27] regarding the dominance of vocabulary studies. Of the 119 games in 111 papers, 51 games (42.86\%) were aimed at vocabulary or used vocabulary as a means of performance testing. Additionally, vocabulary skills were 
targeted amongst the mixed language skill papers, making vocabulary the most popular language skill in DGBLL by an overwhelming margin.

Major elements were excluded from the language skills table to try and reduce redundant results. However, communication analysis needs further explanation due to the exclusion. Papers that targeted communication were the most likely to use a massively multiplayer online (MMO) game. The most popular MMO was Second Life, with six instances, followed by World of Warcraft (WoW) [157], and Ragnarok Online [158], which were used in three and two papers, respectively. The frequent use of MMOs (which often contain many game elements) creates an issue with unique major elements that need to be mentioned. When targeting communication skills, the games chosen or built for these studies contained four unique major elements: social networking, teams, exploration, and virtual economy. This combination of major and minor elements allowed for more freedom for the participants and encouraged interaction in the target language [88].

Another issue was that input skills were rarely the focus of studies and the listening skill only featured in one paper by Müller [138]. Consequently, the low number of papers $(n=4)$ meant that one game with unique elements would ultimately occupy the minor elements cell. In the only listening skill paper, Müller's study, the participants that used the bespoke DGBLL application Medicina were better able to identify words aurally. The game only had five elements, feedback, theme, points, leaderboard, and time pressure, and had significantly positive results. Overall, the input skills papers were very low on game elements, with 18 elements in total.

Output skills included some interesting DGBLL implementations such as Her Story [159] for writing, and Khatoony's bespoke virtual reality (VR) game [121] for speaking. Lee [103] conducted a study using Her Story, which is a unique COTS game for entertainment where players follow a police case through interview tapes. The participants in this study were successful in using the interactive game to inspire their creative writing. The VR game, in contrast, had very few game elements with the focus on the theme of each room and the interaction between the participant and the non-player character. This study, in particular, isolated the theme element in game-based learning, but the use of VR technology could have influenced the outcome due to the novelty and device-driven immersion factors.

Grammar also lacked in studies and was the only language skill that regularly implemented the learning element. Both of the games that contained learning, English Extras ${ }^{\circledR}$ In Business with A, An, and The and Phrasal Nerds [160], were COTS games for education. These systems also contained narratives and taught grammar points before the participants went through the story. This combination worked effectively, according to Kao's [83] findings. Fallah [96] compared Phrasal Nerds with Kahoot! [161] and found that the narrative had an influence in participants choosing to use Phrasal Nerds over Kahoot!.

Studies that included multiple language skills contained the highest percentage of COTS games. Targeting multiple skills allowed for greater creativity within the DGBLL implementation. For example, Liang [49] used Second Life as a multimodal DGBLL to aid in the elocution of words through communication activities and storytelling exercises. Liang's strategy was especially effective by employing the narrative element. Another example is the bespoke application called ImALeG [94]. ImALeG was created to teach Amazigh after its re-introduction into the school system in Morocco by having students explore the environment to collect alphabets. The exploration and narrative elements were a major part of the design, which included a companion and dialogue with non-player characters.

\subsection{What Are Some Lesser Used Game Design Elements in DGBLL Applications That Have Shown Potential?}

Marczewski's framework includes specific features of games, which helps to identify uniquely implemented strategies for language learning. A few low-frequency elements are discussed in this section. 


\subsubsection{Boss Battles for Assessment}

Some applications had self-contained assessment tools. Assessment using the quiz COTS game Kahoot! had mixed reviews [104,134]. One bespoke DGBLL application created by Ansteeg [90] that had positive responses from the participants featured an assessment using a boss battle. Although boss battles were also regularly found in the games for entertainment used for DGBLL $(41.67 \%)$, the feature was used more as a device or affordance for stimulating communication in the target language [38]. Therefore, using boss battles for assessing knowledge makes Ansteeg's prototype unique. Boss battles require more work to implement since other elements are necessary to support the feature, such as narrative/story and theme.

\subsubsection{Collecting and Trading}

Collecting items was featured in $5.77 \%$ of the bespoke games and $7 \%$ overall. Collection methods varied widely amongst the games. Economou's [105] British Sign Language application had users explore the environment to find and collect target language to fight enemies (this is similar to [90]). In contrast, Nori School [32] required users to defeat monsters to collect items. Trading involves being able to give and receive items from other users or game characters.

\subsubsection{Anonymity and Anxiety}

The use of technology to mediate communication between language learners was shown to reduce anxiety toward using the language [162]. The game element anonymity, which allows a user to mask their identity or assume the identity of an avatar, fulfils this purpose. Language learners have found it easier to chat in a target language using a messaging system or find that using such a system increases their confidence [163,164]. Therefore, it is understandable that using a massively multiplayer online game with chat functionality can facilitate a similar type of environment. Collaboration during social gaming can contribute to language skills and practice that is outside of the scope of traditional classroom teaching. A good example is Zheng's [38] study on WoW, which observed how coaction creates a meaningful experience during language practice.

\subsubsection{Networking, Questing, and Exploring Together}

Social networking is the ability to communicate with other users. Questing involves guiding a user through content by assigning tasks. Both social networking and questing are uncommon elements in DGBLL (occurring in 16\% and 19\% of games, respectively). Although they are rarely used together in total $(7 \%)$, they are more regularly found together if one is present (around $40 \%$ ). Interestingly, exploration, an uncommon element found in $22 \%$ of the total game population, occurred $100 \%$ of the time when questing and social networking were present. This type of design allows users to acquire language incidentally and practice language through communicating and adventure together. WoW has been used in a few studies that focused on communication and found mostly positive observations [12,38,44,92]. Another game called MeetMe used by Yamazaki [68] lacked questing because the game was mainly for socializing. However, Yamazaki provided the participants quests outside of the application. Yamazaki found that the participants were encouraged to use the target language when communicating with native speakers to aid them in completing the quests.

\subsubsection{Points, Badges, and Leaderboards}

The gameful approach review by Dichev [25] found that $27 \%$ of the gamification studies used a combination of points, badges, and leaderboards. However, in DGBLL, this combination is found far less frequently. Points were commonly present in games $(52 \%)$. In contrast, leaderboards $(17 \%)$ and badges $(14 \%)$ were uncommon. The combination of these three elements was only found in $5 \%$ of the analyzed games. Therefore, this combination of elements is rarely found and distinguishes DGBLL from other gameful approaches. 


\subsection{Limitations}

The papers reviewed during this study were limited to those written in English, so relevant studies in other languages were not included. Another limitation, which is common in literature reviews, was that the keywords were specific (in this case, focused on serious and digital games). During the literature search, some papers with similar concepts and experiments were labelled with alternative words such as simulations, computer-aided language learning, or technology-enhanced language learning. Therefore, there may be papers related to the topic presented in this study that were missed due to the wording.

Another important limitation is related to access to the applications mentioned in the analyzed papers. It was possible to find some of the games, but many of the game elements were extracted from screenshots and descriptions instead of hands-on experience with the applications.

\section{Conclusions}

DGBLL is still a growing field and requires more data to provide implementation guidelines for the education community. This review of the literature provides a valuable summary regarding game design patterns found in language education and how these features can be used. The most frequent features included providing feedback, having a theme, telling a story, progression through stages of increasing difficulty and, finally, giving points. However, only a few studies showed causal evidence of specific or combinations of elements creating the positive outcome, which creates issues with generalizing the effectiveness of their implementations.

Unlike Hung's review [26], the analysis in this paper showed similar usage of bespoke games versus COTS games in DGBLL, where $52 \%$ of the games were bespoke and $48 \%$ of the games were off-the-shelf. However, games for educational purposes $(n=88)$ far exceeded the number of games for entertainment $(n=12)$. Bespoke and COTS games also share the same three most frequent game elements: feedback, theme, and points. The studies using this gameful approach were found to produce predominantly positive results.

Tertiary education and adult participants outnumbered other age groups by a significant amount. Additionally, research was severely lacking in the preschool and secondary school age groups. Input, output, and grammar language skills were lacking in research compared with vocabulary and communication studies. Input, especially, suffered from a dearth of data, with the listening skill only found in 1 paper out of 111 . Therefore, future research will benefit from addressing these less-targeted categories to better understand the impact of DGBLL.

Finally, this literature review covers the number of game elements and their frequency patterns but does not cover the quality of their implementation. The quality of a game element refers to factors such as the creativity or impact of a given element. For example, the points element is commonly found in games, but its implementation can manifest in various ways, such as a leaderboard entry or avatar levelling. Within these manifestations, which is the most effective and why? These are the types of questions that need to be addressed in further reviews.

Author Contributions: Conceptualization, T.G. and J.A.-M.; methodology, T.G. and J.A.-M.; validation, J.A.-M.; formal analysis, T.G.; investigation, T.G.; resources, J.A.-M.; data curation, T.G.; writing —original draft preparation, T.G.; writing—review and editing, T.G. and J.A.-M.; visualization, T.G.; supervision, J.A.-M.; project administration, J.A.-M. All authors have read and agreed to the published version of the manuscript.

Funding: This research received no external funding.

Conflicts of Interest: The authors declare no conflict of interest. The funders had no role in the design of the study; in the collection, analyses, or interpretation of data; in the writing of the manuscript, or in the decision to publish the results. 


\section{Abbreviations}

The following abbreviations are used in this manuscript:

DGBLL Digital game-based language learning

COTS Commercial off-the-shelf

MMO Massively multiplayer online game

WoW World of Warcraft

\section{Appendix A}

Table A1. Table of mentioned game elements.

\begin{tabular}{|c|c|}
\hline Name of Element & Description \\
\hline On-boarding/Tutorials & In-game instructions on how to use the software. \\
\hline Signposting & $\begin{array}{c}\text { The presence of hints and helpful indicators that can be } \\
\text { initiated by the user or when the system determines that the } \\
\text { user requires aid. }\end{array}$ \\
\hline Progress/Feedback & $\begin{array}{l}\text { Any system that shows the user their progress in the overall } \\
\text { application or shows the user the result of their response(s) } \\
\text { or reaction. }\end{array}$ \\
\hline Theme & $\begin{array}{l}\text { Repeating non-playing characters or uniformity in the } \\
\text { educational content's subject(s). }\end{array}$ \\
\hline Narrative/Story & $\begin{array}{c}\text { The presence of a story explaining or driving the events } \\
\text { within the game. }\end{array}$ \\
\hline Time pressure & $\begin{array}{c}\text { The presence of in-game events that need to be completed } \\
\text { within a certain amount of time. }\end{array}$ \\
\hline Consequences & $\begin{array}{l}\text { A feedback system for choices that are made by the user. } \\
\text { The difference between loss aversion and consequences is } \\
\text { that loss aversion is related to fear and consequences are } \\
\text { part of the system. }\end{array}$ \\
\hline Fixed Reward Schedule & $\begin{array}{l}\text { The system rewards the user based on completed actions } \\
\text { such as completing a level or achieving a milestone. }\end{array}$ \\
\hline Guilds/Teams & $\begin{array}{l}\text { The ability for players to group up within the game for } \\
\text { collaborative tasks or communication. }\end{array}$ \\
\hline Social Network & $\begin{array}{l}\text { The ability for users to find and add people to a personally } \\
\text { accessible list. }\end{array}$ \\
\hline Social Discovery & $\begin{array}{l}\text { A more specialized system than Social Network that tries to } \\
\text { find suitable users to match with for example finding a } \\
\text { partner on a dating application or specific roles such as a } \\
\text { healer or damage dealer for a quest or dungeon. }\end{array}$ \\
\hline Exploration & The ability for players to move around the game world. \\
\hline Customisation & $\begin{array}{c}\text { Allowing users to customize the way they are presented } \\
\text { within the system such as avatars. }\end{array}$ \\
\hline Learning/New Skills & $\begin{array}{l}\text { The presence of a learning system that teaches the user or } \\
\text { the user's avatar such as new spells in entertainment games } \\
\text { or grammar points in educational settings. }\end{array}$ \\
\hline Quests & The presence of tasks for the user to complete. \\
\hline Levels/Progression & $\begin{array}{l}\text { The difference between Progress/Feedback and } \\
\text { Levels/Progression is that the latter refers to the stages } \\
\text { themselves or a visual representation of where to go next. }\end{array}$ \\
\hline
\end{tabular}


Table A1. Cont.

\begin{tabular}{|c|c|}
\hline Name of Element & Description \\
\hline Boss Battles & $\begin{array}{l}\text { The presence of a suitably intense challenge that could be } \\
\text { necessary to continue to the next stage, to complete the } \\
\text { game or to loot for required items/equipment to progress } \\
\text { further. }\end{array}$ \\
\hline Collect \& Trade & $\begin{array}{c}\text { The presence of an inventory-type system where users can } \\
\text { collect and/or trade items that are not regarded as points or } \\
\text { currency. }\end{array}$ \\
\hline Sharing Knowledge & $\begin{array}{l}\text { The ability for users to create informational material for the } \\
\text { purpose of helping others such as FAQs, guides or forums. }\end{array}$ \\
\hline Anonymity & $\begin{array}{l}\text { Any system where a user's real identity is hidden through } \\
\text { features such as usernames or "allow anonymous } \\
\text { answering" settings. }\end{array}$ \\
\hline Anarchy & $\begin{array}{l}\text { The ability for users to create events or do actions that are } \\
\text { destructive in some way. }\end{array}$ \\
\hline Points/Experience Points & $\begin{array}{l}\text { The presence of a score related to an activity or action that } \\
\text { may or may not increase the user's level. }\end{array}$ \\
\hline Leaderboards/Ladders & Any system with a user ranking system. \\
\hline Badges/Achievements & $\begin{array}{l}\text { Any system with a milestone indicator that is accompanied } \\
\text { by textual/visual recognition. }\end{array}$ \\
\hline Virtual Economy & $\begin{array}{l}\text { The presence of a buying/selling system with goods or } \\
\text { services that a user has access to via a fictional currency that } \\
\text { can be earned or bought with real money. }\end{array}$ \\
\hline
\end{tabular}

Table A2. Table of analyzed bespoke games.

\begin{tabular}{cc}
\hline Name of Game & Papers \\
\hline Online vision-based motion games & {$[29]$} \\
\hline Nori School & {$[32]$} \\
\hline The request game & {$[53]$} \\
\hline Virtual Language Patient & {$[107]$} \\
\hline Medicina & {$[36,138]$} \\
\hline It's a Deal! & {$[75]$} \\
\hline Immersive RPG for English pragmatics & {$[37]$} \\
\hline Speech-Enabled Virtual Scenarios & {$[89]$} \\
\hline ELMORPG & {$[114,119]$} \\
\hline VirtUAM & {$[39]$} \\
\hline Word Score & {$[122]$} \\
\hline HOPSCOTCH exer-game & {$[109]$} \\
\hline VocaMono & {$[118]$} \\
\hline eBook-based game & {$[76]$} \\
\hline GeCALL & {$[110]$} \\
\hline Children Make Terrible Pets made by Microsoft Games Studio & {$[41]$} \\
\hline Alphabetical sound ariculation game & {$[78]$} \\
\hline MEL & {$[40]$} \\
\hline & {$[77]$} \\
\hline
\end{tabular}


Table A2. Cont.

\begin{tabular}{|c|c|}
\hline Name of Game & Papers \\
\hline Cao Chung Weighing an Elephant & [123] \\
\hline The Elephant and the Blind Men & [123] \\
\hline Simulated real-world 3D-DGBLL & [42] \\
\hline Contextual learning RPGs & [120] \\
\hline Handheld sensor-based vocabulary games & [112] \\
\hline RPG for incidental lexicon acquisition & [90] \\
\hline WiCFG & [59] \\
\hline Interactive learning environment & {$[100,127]$} \\
\hline Virtual Knee Surgery by Edheads & [126] \\
\hline Scenario-Based Interactive Environment & [136] \\
\hline Prêt à négocier & {$[64]$} \\
\hline The Conference Interpreter & [135] \\
\hline Game-Based System for ASL using Kinect & {$[66]$} \\
\hline Little Ingenius & [81] \\
\hline Idiomatico & [130] \\
\hline ARCS-based game & [70] \\
\hline My Pet Shop & [115] \\
\hline ImALeG & [94] \\
\hline Kes Sesi & [48] \\
\hline Cool Nurse & [74] \\
\hline Virtual Reality Assisted Language Learning game & [121] \\
\hline Enskill English & [124] \\
\hline TALSQ & {$[72]$} \\
\hline DiMaCA-based application & [21] \\
\hline MMORPG-based English Learning Environment (MELE) & {$[84]$} \\
\hline Spaceteam ESL & [71] \\
\hline Competitive Cloze Game & [87] \\
\hline Complexity-based competition game & [86] \\
\hline SELS & [51] \\
\hline Contextual RPG & [85] \\
\hline Wordsearch & [52] \\
\hline BSL RPG game & [105] \\
\hline
\end{tabular}


Table A3. Table of analyzed off-the-shelf Games.

\begin{tabular}{|c|c|}
\hline Name of Game & Papers \\
\hline PaRappa the Rapper 2 & {$[30]$} \\
\hline Second Life & {$[7,31,34,49,55,56,60,80]$} \\
\hline Ragnarok Online & {$[20,88]$} \\
\hline My Word Coach & [54] \\
\hline $\begin{array}{l}\text { Sistema Hipermedia Adaptativo para la } \\
\text { ensenanza de idiomas en entorno Linex }\end{array}$ & [33] \\
\hline World of Warcraft & {$[12,36,38,44,92]$} \\
\hline Mingoville & [57] \\
\hline Talking Island & {$[116,117]$} \\
\hline Family and Friends & {$[35,131]$} \\
\hline Divine Divinity & {$[108]$} \\
\hline L.A. Noire & [79] \\
\hline Food Force & [111] \\
\hline Writing Pal & [58] \\
\hline British Council LearnEnglish Kids & [98] \\
\hline Quizlet & {$[62,67,113,125]$} \\
\hline The Walking Dead & [99] \\
\hline Adventure German & {$[63,65]$} \\
\hline 3rd World Farmer & [113] \\
\hline Defense of the Ancients & [91] \\
\hline gamestolearnenglish.com & [61] \\
\hline Hansel and Gretel by Mindshapes Ltd. & [128] \\
\hline Lingo Arcade & [43] \\
\hline Energy City & [45] \\
\hline Kahoot! & {$[67,96,104,132,134]$} \\
\hline Nearpod & [67] \\
\hline Galli Galli Sim Sim games & [129] \\
\hline Meet-Me & [68] \\
\hline Bud's First Words & [93] \\
\hline ESL Games World & [69] \\
\hline Shoot 'Em & [46] \\
\hline Scramble 'Em & [46] \\
\hline Hujiang Fun Vocabulary & [82] \\
\hline Baicizhan & [82] \\
\hline New Oriental Fun Vocabulary & [82] \\
\hline Kingsoft Vocabulary & [82] \\
\hline ABCYa.com & [47] \\
\hline The Sims & [102] \\
\hline Vocabulary.com & [101] \\
\hline Her Story & [103] \\
\hline Storium & [73] \\
\hline
\end{tabular}


Table A3. Cont.

\begin{tabular}{cc}
\hline Name of Game & Papers \\
\hline Ba'alty & {$[137]$} \\
\hline Educaplay & {$[95]$} \\
\hline English Extras in Business with A, An, and The & {$[83]$} \\
\hline LearningApps.org & {$[125]$} \\
\hline Escribo Play and Learn & {$[50]$} \\
\hline Socrative & {$[133]$} \\
\hline Practice Spanish: Study Abroad & {$[97]$} \\
\hline Phrasal Nerds & {$[96]$} \\
\hline Liulishuo & {$[106]$} \\
\hline
\end{tabular}

\section{References}

1. Gardner, R.C.; Lalonde, R.N.; Moorcroft, R.; Evers, F.T. Second language attrition: The role of motivation and use. J. Lang. Soc. Psychol. 1987, 6, 29-47. [CrossRef]

2. Flores, J.F.F. Using gamification to enhance second language learning. Digit. Educ. Rev. 2015, 27, 32-54.

3. Govender, T.; Arnedo-Moreno, J. A Survey on Gamification Elements in Mobile Language-Learning Applications. In Eighth International Conference on Technological Ecosystems for Enhancing Multiculturality; Association for Computing Machinery: New York, NY, USA, 2020; pp. 669-676. [CrossRef]

4. Susi, T.; Johannesson, M.; Backlund, P. Serious Games-An Overview. Technical Report HS-IKI-TR-07-001). 2007. Available online: https: / /www.semanticscholar.org/paper/Serious-Games-\%3A-An-Overview-Susi-Johannesson/35627442d7073968 b06868821722e5db8c21062d (accessed on 1 June 2021).

5. Plotkin, A. Werewolf; Board Game; Looney Labs: College Park, MD, USA, 1997.

6. Out of the Box Publishing. Apples to Apples; Board Game; Mattel: El Segundo, CA, USA, 1999.

7. Peterson, M. EFL Learner Collaborative Interaction in Second Life. ReCALL 2012, 24, 20-39. [CrossRef]

8. Linden Lab. Second Life; Game [Microsoft Windows]; Linden Lab: San Francisco, CA, USA, 2003.

9. Hsiao, H.C. A brief review of digital games and learning. In Proceedings of the DIGITEL 2007: First IEEE International Workshop on Digital Game and Intelligent Toy Enhanced Learning, Jhongli, Taiwan, 26-28 March 2007; pp. 124-129. [CrossRef]

10. Karagiorgas, D.N.; Niemann, S. Gamification and Game-Based Learning. J. Educ. Technol. Syst. 2017, 45, 499-519. [CrossRef]

11. Chik, A. Learner autonomy development through digital gameplay. Digit. Cult. Educ. 2011, 3, 30-44.

12. Rama, P.S.; Black, R.W.; van Es, E.; Warschauer, M. Affordances for Second Language Learning in "World of Warcraft". ReCALL 2012, 24, 322-338. [CrossRef]

13. Thorne, S.; Fischer, I.; Lu, X. The semiotic ecology and linguistic complexity of an online game world. ReCALL 2012, 24, 279-301. [CrossRef]

14. Scholz, K. Encouraging Free Play: Extramural Digital Game-Based Language Learning as a Complex Adaptive System. CALICO J. 2017, 34, 39-57. [CrossRef]

15. Sundqvist, P. Commercial-off-the-shelf games in the digital wild and L2 learner vocabulary. Lang. Learn. Technol. 2019, 23, 87-113.

16. Deterding, S.; Dixon, D.; Khaled, R.; Nacke, L. From game design elements to gamefulness: Defining "gamification". In Proceedings of the 15th International Academic MindTrek Conference: Envisioning Future Media Environments, Tampere, Finland, 28-30 September 2011; pp. 9-15.

17. Lucasfilm Games. Monkey Island; Game [Atari ST, Amiga, DOS, Windows, Classic Mac OS, macOS, Mega-CD, PlayStation 2, XBLA, WiiWare, PSN, iOS]; Disney Interactive: Glendale, CA, USA, 1990.

18. Daedalic Entertainment. Deponia; Game [Microsoft Windows, OS X, Linux, iOS, PlayStation 4, Nintendo Switch, Xbox One]; Daedalic Entertainment: Hamburg, Germany, 2012.

19. Prensky, M. Digital Game-Based Learning; McGraw-Hill Pub. Co.: New York, NY, USA, 2004.

20. Reinders, H.; Wattana, S. Affect and willingness to communicate in digital game-based learning. ReCALL 2015, $27,38-57$. [CrossRef]

21. Ayedoun, E.; Hayashi, Y.; Seta, K. Adding Communicative and Affective Strategies to an Embodied Conversational Agent to Enhance Second Language Learners' Willingness to Communicate. Int. J. Artif. Intell. Educ. 2019, 29, 29-57. [CrossRef]

22. All, A.; Nuñez Castellar, E.P.; Van Looy, J. Assessing the effectiveness of digital game-based learning: Best practices. Comput. Educ. 2016, 92-93, 90-103. [CrossRef]

23. Linehan, C.; Kirman, B.; Lawson, S.; Chan, G. Practical, appropriate, empirically-validated guidelines for designing educational games. In Proceedings of the SIGCHI Conference on Human Factors in Computing Systems, Vancouver, BC, Canada, 7-12 May 2011; pp. 1979-1988. [CrossRef] 
24. Boyle, E.A.; Hainey, T.; Connolly, T.M.; Gray, G.; Earp, J.; Ott, M.; Lim, T.; Ninaus, M.; Ribeiro, C.; Pereira, J. An update to the systematic literature review of empirical evidence of the impacts and outcomes of computer games and serious games. Comput. Educ. 2016, 94, 178-192. [CrossRef]

25. Dichev, C.; Dicheva, D. Gamifying education: What is known, what is believed and what remains uncertain: A critical review. Int. J. Educ. Technol. High. Educ. 2017, 14, 1. [CrossRef]

26. Hung, H.T.; Yang, J.C.; Hwang, G.J.; Chu, H.C.; Wang, C.C. A scoping review of research on digital game-based language learning. Comput. Educ. 2018, 126, 89-104. [CrossRef]

27. Xu, Z.; Chen, Z.; Eutsler, L.; Geng, Z.; Kogut, A. A scoping review of digital game-based technology on English language learning. Educ. Technol. Res. Dev. 2020, 68, 877. [CrossRef]

28. Shute, V.J.; Ke, F. Games, learning, and assessment. In Assessment in Game-Based Learning; Springer: Berlin/Heidelberg, Germany, 2012; pp. 43-58.

29. Hao, Y.; Hong, J.C.; Jong, J.T.; Hwang, M.Y.; Su, C.Y.; Yang, J.S. Non-native Chinese language learners' attitudes towards online vision-based motion games. Br. J. Educ. Technol. 2010, 41, 1043-1053. [CrossRef]

30. deHaan, J.; Michael Reed, W.; Kuwada, K. The effect of interactivity with a music video game on second language vocabulary recall. Lang. Learn. Technol. 2010, 14, 74-94.

31. Peterson, M. Learner participation patterns and strategy use in Second Life: An exploratory case study. ReCALL 2010, 22, 273-292. [CrossRef]

32. Suh, S.; Kim, S.; Kim, N. Effectiveness of MMORPG-based instruction in elementary English education in Korea. J. Comput. Assist. Learn. 2010, 26, 370-378. [CrossRef]

33. Aghlara, L.; Tamjid, N.H. The effect of digital games on Iranian children's vocabulary retention in foreign language acquisition. Procedia Soc. Behav. Sci. 2011, 29, 552-560. [CrossRef]

34. Wehner, A.; Gump, A.; Downey, S. The effects of Second Life on the motivation of undergraduate students learning a foreign language. Comput. Assist. Lang. Learn. 2011, 24, 277-289. [CrossRef]

35. Jalali, S.; Dousti, M. Vocabulary and grammar gain through computer educational games. GEMA Online J. Lang. Stud. 2012, 12, 1077-1088.

36. Müller, A. Research-based design of a medical vocabulary videogame. Int. J. Pedagog. Learn. 2012, 7, 122-134. [CrossRef]

37. Cornillie, F.; Clarebout, G.; Desmet, P. Between learning and playing? Exploring learners' perceptions of corrective feedback in an immersive game for English pragmatics. ReCALL 2012, 24, 257-278. [CrossRef]

38. Zheng, D.; Newgarden, K.; Young, M.F. Multimodal Analysis of Language Learning in World of Warcraft Play: Languaging as Values-Realizing. ReCALL 2012, 24, 339-360. [CrossRef]

39. Berns, A.; Gonzalez-Pardo, A.; Camacho, D. Game-like language learning in 3-D virtual environments. Comput. Educ. 2013, 60, 210-220. [CrossRef]

40. Ongoro, C.; Mwangoka, J. Using Game-Based approach to enhance language learning for preschoolers in Tanzania. In Proceedings of the 2nd Pan African International Conference on Science, Computing and Telecommunications (PACT 2014), Arusha, Tanzania, 14-18 July 2014, 2014; pp. 121-126. [CrossRef]

41. Young, S.C.; Wang, Y.H. The Game Embedded CALL System to Facilitate English Vocabulary Acquisition and Pronunciation. Educ. Technol. Soc. 2014, 17, 239-251.

42. Neville, D. The story in the mind: The effect of 3D gameplay on the structuring of written L2 narratives. ReCALL 2015, 27, 21-37. [CrossRef]

43. Eshelman, T. Digital game based learning's (GBL) impact on foreign language (FL) vocabulary cquisition. Turk. Online J. Educ. Technol. 2017, 2017, 183-202.

44. Scholz, K.; Schulze, M. Digital-gaming trajectories and second-language development. Lang. Learn. Technol. 2017, 21, 100-120.

45. Franciosi, S. The effect of computer game-based learning on FL vocabulary transferability. Educ. Technol. Soc. 2017, 20, 123-133.

46. Dedeaux, T.; Hartsell, T. Comparison Between Two Types of Educational Computer Games. Simul. Gaming 2018, 49. [CrossRef]

47. Zulkiply, N.; Aziz, A. The effects of digital game-based learning on early English literacy task for non-native speakers. Asia-Pac. J. Res. Early Child. Educ. 2019, 13, 123-140. [CrossRef]

48. Samur, Y. Kes Sesi: A mobile game designed to improve kindergarteners' recognition of letter sounds. J. Comput. Assist. Learn. 2018, 35. [CrossRef]

49. Liang, M.Y. Beyond elocution: Multimodal narrative discourse analysis of L2 storytelling. ReCALL 2018, 31, 1-19. [CrossRef]

50. Amorim, A.; Jeon, L.; Abel, Y.; Felisberto, E.; Barbosa, L.; Dias, N. Using Escribo Play Video Games to Improve Phonological Awareness, Early Reading, and Writing in Preschool. Educ. Res. 2020, 49, 118-197. [CrossRef]

51. Chang, Y.H.; Lin, P.R.; Lu, Y.T. Development of a kinect-based english learning system based on integrating the ARCS model with situated learning. Sustainability 2020, 12, 2037. [CrossRef]

52. Goumas, S.; Terzopoulos, G.; Tsompanoudi, D.; Iliopoulou, A. Wordsearch, an educational game in language learning. J. Eng. Sci. Technol. Rev. 2020, 13, 50-56. [CrossRef]

53. Yang, H.C.; Zapata-Rivera, D. Interlanguage Pragmatics with a Pedagogical Agent: The Request Game. Comput. Assist. Lang. Learn. 2010, 23, 395-412. [CrossRef]

54. Cobb, T.; Horst, M. Does “Word Coach" Coach Words? CALICO J. 2011, 28, 639-661. [CrossRef] 
55. Liou, H.C. The roles of Second Life in a college computer-assisted language learning (CALL) course in Taiwan, ROC. Comput. Assist. Lang. Learn. 2012, 25, 365-382. [CrossRef]

56. Liang, M.Y. Foreign ludicity in online role-playing games. Comput. Assist. Lang. Learn. 2012, 25, 455-473. [CrossRef]

57. Anyaegbu, R.; Ting, W.; Li, Y. Serious Game Motivation in an EFL Classroom in Chinese Primary School. Turk. Online J. Educ. Technol. 2012, 11, 154-164.

58. Allen, L.K.; Crossley, S.A.; Snow, E.L.; McNamara, D.S. L2 Writing Practice: Game Enjoyment as a Key to Engagement. Lang. Learn. Technol. 2014, 18, 124-150.

59. Hung, H.C.; Young, S.S.C.; Lin, C.P. No student left behind: A collaborative and competitive game-based learning environment to reduce the achievement gap of EFL students in Taiwan. Technol. Pedagog. Educ. 2015, 24, 35-49. [CrossRef]

60. Lan, Y.J. Contextual EFL Learning in a 3D Virtual Environment. Lang. Learn. Technol. 2015, 19, 16-31.

61. Salavati, M.; Salehi, H. Impact of Using Instructional Video Games as an on EFL Learners' Vocabulary Retention. Univers. J. Educ. Res. 2016, 4, 2724-2728.

62. Xerou, E.; Papadima-Sophocleous, S.; Parmaxi, A. A Social Constructionist Approach to Teaching and Learning Vocabulary for Italian for Academic Purposes. In Proceedings of the EUROCALL 2016 Conference, Limassol, Cyprus, $24-27$ August 2016.

63. Alyaz, Y.; Genc, Z. Digital Game-Based Language Learning in Foreign Language Teacher Education. Turk. Online J. Distance Educ. 2016, 17. [CrossRef]

64. Cardoso, W.; Rueb, A.; Grimshaw, J. Can an interactive digital game help French learners improve their pronunciation? CALL Clim. Chang. Adapt. Turbul. Glob. Cond. 2017, 67-72. [CrossRef]

65. Alyaz, Y.; Spaniel-Weise, D.; Gürsoy, E. A Study on Using Serious Games in Teaching German as a Foreign Language. J. Educ. Learn. 2017, 6, 250. [CrossRef]

66. Kamnardsiri, T.; Hongsit, L.O.; Khuwuthyakorn, P.; Wongta, N. The Effectiveness of the Game-Based Learning System for the Improvement of American Sign Language using Kinect. Electron. J. Learn. 2017, 15, 2017-2283.

67. Karaaslan, H.; Kılıç, N.; Yalcin, G.; Gullu, A. Students' Reflections on Vocabulary Learning through Synchronous and Asynchronous Games and Activities. Turk. Online J. Distance Educ. 2018, 19. [CrossRef]

68. Yamazaki, K. Computer-assisted learning of communication (CALC): A case study of Japanese learning in a 3D virtual world. $\operatorname{ReCALL}$ 2018, 30, 214-231. [CrossRef]

69. Utku, Ö.; Dolgunsöz, E. Teaching EFL Vocabulary to Young Digital Natives through Online Games: A Study with Turkish 5th Grade EFL Learners. Int. Online J. Educ. Teach. 2018, 5, 115-130.

70. Wu, T.T. Improving the effectiveness of English vocabulary review by integrating ARCS with mobile game-based learning. $J$. Comput. Assist. Learn. 2018, 34, 315-323. [CrossRef]

71. Cardoso, W.; Waddington, D.; Kiforo, E.; Sénécal, A.M. Shouting in space: Promoting oral reading fluency with Spaceteam ESL. CALL Complex. 2019, 69-74. [CrossRef]

72. Ongoro, C.A.; Mwangoka, J. Effects of digital games on enhancing language learning in Tanzanian preschools. Knowl. Manag. Learn. Int. J. 2019, 11, 325-344.

73. Bal, M. Use of Digital Games in Writing Education: An Action Research on Gamification. Contemp. Educ. Technol. 2019, 10, 246-271. [CrossRef]

74. Rachayon, S.; Soontornwipast, K. The Effects of Task-based Instruction Using a Digital Game in a Flipped Learning Environment on English Oral Communication Ability of Thai Undergraduate Nursing Students. Engl. Lang. Teach. 2019, 12, 12-32. [CrossRef]

75. Guillén-Nieto, V.; Aleson-Carbonell, M. Serious games and learning effectiveness: The case of It's a Deal! Comput. Educ. 2012, 58, 435-448. [CrossRef]

76. Smith, G.G.; Li, M.; Drobisz, J.; Park, H.R.; Kim, D.; Smith, S.D. Play games or study? Computer games in eBooks to learn English vocabulary. Comput. Educ. 2013, 69, 274-286. [CrossRef]

77. Sandberg, J.; Maris, M.; Hoogendoorn, P. The added value of a gaming context and intelligent adaptation for a mobile learning application for vocabulary learning. Comput. Educ. 2014, 76, 119-130. [CrossRef]

78. Homer, B.; Kinzer, C.; Plass, J.; Letourneau, S.; Hoffman, D.; Bromley, M.; Hayward, E.; Turkay, S.; Kornak, Y. Moved to learn: The effects of interactivity in a Kinect-based literacy game for beginning readers. Comput. Educ. 2014, 74, 37-49. [CrossRef]

79. Shahriarpour, N.; kafi, Z. On the Effect of Playing Digital Games on Iranian Intermediate EFL Learners' Motivation toward Learning English Vocabularies. Procedia Soc. Behav. Sci. 2014, 98, 1738-1743. [CrossRef]

80. Chen, J.C. The crossroads of English language learners, task-based instruction, and 3D multi-user virtual learning in Second Life. Comput. Educ. 2016, 102, 152-171. [CrossRef]

81. Pons Lelardeux, C.; Michel, G.; Panzoli, D.; Gilles, P.; Minguella-Canela, J.; Yassine-Diab, N.; Lagarrigue, P. Improving mechanical engineering vocabulary through the use of a game. Procedia Manuf. 2017, 13, 1432-1439. [CrossRef]

82. Yu, Z. Differences in serious game-aided and traditional English vocabulary acquisition. Comput. Educ. 2018, 127, 214-232. [CrossRef]

83. Kao, C.W. The effect of a digital game-based learning task on the acquisition of the English Article System. System 2020, 95, 102373. [CrossRef]

84. Yang, J.C.; Chen, S.Y. An investigation of game behavior in the context of digital game-based learning: An individual difference perspective. Comput. Hum. Behav. 2020, 112, 106432. [CrossRef] 
85. Lin, C.J.; Hwang, G.J.; Fu, Q.; Cao, Y.H. Facilitating EFL students' English grammar learning performance and behaviors: A contextual gaming approach. Comput. Educ. 2020, 152, 103876. [CrossRef]

86. Yang, Q.F.; Chang, S.C.; Hwang, G.J.; Zou, D. Balancing cognitive complexity and gaming level: Effects of a cognitive complexitybased competition game on EFL students' English vocabulary learning performance, anxiety and behaviors. Comput. Educ. 2020, 148, 103808. [CrossRef]

87. Chen, S.; Chang, Y.M. The impacts of real competition and virtual competition in digital game-based learning. Comput. Hum. Behav. 2019, 104, 106171. [CrossRef]

88. Hayo, R.; Sorada, W. Learn English or die: The effects of digital games on interaction and willingness to communicate in a foreign language. Digit. Cult. Educ. 2011, 3, 4-28.

89. Hazel, M.; Nancie, G.; Mervyn, J. Interactive Language Learning through Speech-Enabled Virtual Scenarios. Adv. Hum.-Comput. Interact. 2012, 2012, 389523.

90. Ansteeg, L. Incidental Lexicon Acquisition through Playful Interaction. Int. J. Emerg. Technol. Learn. (iJET) 2015, 10, 4-10. [CrossRef]

91. Ebrahimzadeh, M.; Alavi, S. Motivating EFL Students: E-Learning Enjoyment as a Predictor of Vocabulary Learning through Digital Video Games. Cogent Educ. 2016, 3, 1255400. [CrossRef]

92. Azman, H.; Dollsaid, N. Applying Massively Multiplayer Online Games (MMOGs) in EFL Teaching. Arab. World Engl. J. 2018, 9, 3-18. [CrossRef]

93. Taghizadeh, M.; Vaezi, S.; Ravan, M. Digital Games, Songs and Flashcards and their Effects on Vocabulary Knowledge of Iranian Preschoolers. Int. J. Engl. Stud. 2018, 5, 156-171.

94. Tazouti, Y.; Boulaknadel, S.; Fakhri, Y. ImALeG: A Serious Game for Amazigh Language Learning. Int. J. Emerg. Technol. Learn. (iJET) 2019, 14. [CrossRef]

95. Castillo-Cuesta, L. Using Digital Games for Enhancing EFL Grammar and Vocabulary in Higher Education. Int. J. Emerg. Technol. Learn. (iJET) 2020, 15, 116. [CrossRef]

96. Fallah Vazirabad, A.; Farrokhi, F. Investigating Digital Apps: Gaming Elements and Learning Context. Int. J. Appl. Linguist. Engl. Lit. 2020, 9, 25. [CrossRef]

97. Gonzalez-Lloret, M.; Díez-Ortega, M.; Payne, S. Gaming alone or together? L2 beginner-level gaming practices. Perspectiva 2020, 38. [CrossRef]

98. AlShaiji, O.A. Video Games Promote Saudi Children's English Vocabulary Retention. Education 2015, 136, $123-132$.

99. Shirazi, M.; Ahmadi, S.D.; Mehrdad, A.G. The Effect of Using Video Games on EFL Learners' Acquisition of Speech Acts of Apology and Request. Theory Pract. Lang. Stud. 2016, 6, 1019-1026. [CrossRef]

100. Yang, J.C.; Quadir, B.; Chen, N.S. Effects of Children's Trait Emotional Intelligence on Digital Game-Based Learning. Int. J. Hum. Comput. Interact. 2019, 35, 374-383. [CrossRef]

101. Mcgregor, K.; Marshall, B.; Julian, S.; Oleson, J. Learning While Playing: A Randomized Trial of Serious Games as a Tool for Word Mastery. Lang. Speech Hear. Serv. Sch. 2019, 50, 596-608. [CrossRef]

102. Lorenset, C.; Tumolo, C. Vocabulary Acquisition in English as a Foreign Language: Digital Gameplaying the Sims. Rev. Ling. Ensino 2019, 22, 1002. [CrossRef]

103. Lee, M. Her Story or their own stories? Digital game-based learning, student creativity, and creative writing. ReCALL 2019, 31, 1. [CrossRef]

104. Hui-Hua, C. Kahoot! In an EFL Reading Class. J. Lang. Teach. Res. 2020, 11, 33-44.

105. Economou, D.; Russi, M.G.; Doumanis, I.; Mentzelopoulos, M.; Bouki, V.; Ferguson, J. Using Serious Games for Learning British Sign Language Combining Video, Enhanced Interactivity, and VR Technology. J. Univ. Comput. Sci. 2020, 26, $996-1016$.

106. Wang, Z.; Han, F. Developing English language learners' oral production with a digital game-based mobile application. PLoS ONE 2021, 16, e0232671. [CrossRef]

107. Walker Nicholas, R.; Trofimovich, P.; Cedergren, H.; Gatbonton, E. Using ASR Technology in Language Training for Specific Purposes: A Perspective from Quebec, Canada. CALICO J. 2011, 28, 721-743. [CrossRef]

108. Vandercruysse, S.; Vandewaetere, M.; Cornillie, F.; Clarebout, G. Competition and students' perceptions in a game-based language learning environment. Educ. Technol. Res. Dev. 2013, 61. [CrossRef]

109. Lucht, M.; Heidig, S. Applying HOPSCOTCH as an exer-learning game in English lessons: two exploratory studies. Educ. Technol. Res. Dev. 2013, 61, 767-792. [CrossRef]

110. Wu, C.J.; Chen, G.D.; Huang, C.W. Using digital board games for genuine communication in EFL classrooms. Educ. Technol. Res. Dev. 2014, 62, 209-226. [CrossRef]

111. Hitosugi, C.; Schmidt, M.; Hayashi, K. Digital Game-based Learning (DGBL) in the L2 Classroom: The Impact of the UN's Off-the-Shelf Videogame, Food Force, on Learner Affect and Vocabulary Retention. CALICO J. 2014, 31, 19-39. [CrossRef]

112. Huang, Y.-M.; Huang, Y.-M. A scaffolding strategy to develop handheld sensor-based vocabulary games for improving students' learning motivation and performance. Educ. Technol. Res. Dev. 2015, 63, 691-708. [CrossRef]

113. Franciosi, S.; Yagi, J.; Tomoshige, Y.; Ye, S. The Effect of a Simple Simulation Game on Long-Term Vocabulary Retention. CALICO J. 2016. [CrossRef]

114. Yang, J.C.; Quadir, B. Effects of Prior Knowledge on Learning Performance and Anxiety in an English Learning Online Role-Playing Game. Educ. Technol. Soc. 2018, 21, 174-185. 
115. Chen, Z.H.; Lee, S.Y. Application-driven educational game to assist young Children in learning English vocabulary. J. Educ. Technol. Soc. 2018, 21, 70-81.

116. Ah-Fur, L.; Shien-Shien, W. Evaluating an online role playing game for promoting the elementary school students' English speaking abilities. In Proceedings of the 2012 8th International Conference on Information Science and Digital Content Technology (ICIDT2012), Jeju, South Korea, 26-28 June 2012; Volume 3, pp. 610-615.

117. Huang, C.W.; Fan, C.Y.; Chi, Y.L.; Wu, C.J.; Chen, G.D. High-Interactive Gaming Learning: Bring Different Learning Benefits to Team Players and Individual Players. In Proceedings of the 2012 IEEE 12th International Conference on Advanced Learning Technologies (ICALT), Rome, Italy, 4-6 July 2012; pp. 354-355.

118. Lo, J.J.; Kuo, T.Y. A Study of Parent-Child Play in a Multiplayer Competitive Educational Game. In Proceedings of the 2013 IEEE 13th International Conference on Advanced Learning Technologies (ICALT), Beijing, China, 15-18 July 2013 ; pp. 43-47.

119. Yang, J.C.; Hsu, H.F. Effects of Prior Knowledge on Cognitive Learning Outcomes within an English Learning Multiplayer Online Role-Playing Game. In Proceedings of the 2013 Second IIAI International Conference on Advanced Applied Informatics (IIAIAAI), Los Alamitos, CA, USA, 31 August-4 September 2013; pp. 166-171.

120. Wang, S.; Hwang, G.; Chen, S. Development of a Contextual Game for Improving English Vocabulary Learning Performance of Elementary School Students in Taiwan. In Proceedings of the 2015 IIAI 4th International Congress on Advanced Applied Informatics, Okayama, Japan, 12-16 July 2015; pp. 268-272. [CrossRef]

121. Khatoony, S. An Innovative Teaching with Serious Games through Virtual Reality Assisted Language Learning. In Proceedings of the 2019 International Serious Games Symposium (ISGS), Tehran, Iran, 26 December 2019; pp. 100-108.

122. Fisser, P.; Voogt, J.; Bom, M. Implementing a Serious Vocabulary Game for Primary School Underachievers. Educ. Inf. Technol. 2013, 18, 165-178. [CrossRef]

123. Si, M. A Virtual Space for Children to Meet and Practice Chinese. Int. J. Artif. Intell. Educ. 2015, 25. [CrossRef]

124. Johnson, W. Data-Driven Development and Evaluation of Enskill English. Int. J. Artif. Intell. Educ. 2019, 29. [CrossRef]

125. Yeşilbağ, S.; Korkmaz, Ö.; Çakir, R. The effect of educational computer games on students' academic achievements and attitudes towards English lesson. Educ. Inf. Technol. 2020, 25, 1-18. [CrossRef]

126. Mohsen, M.A. The Use of Computer-Based Simulation to Aid Comprehension and Incidental Vocabulary Learning. J. Educ. Comput. Res. 2016, 54, 863-884. [CrossRef]

127. Yang, J.C.; Quadir, B.; Chen, N.S. Effects of the Badge Mechanism on Self-Efficacy and Learning Performance in a Game-Based English Learning Environment. J. Educ. Comput. Res. 2016, 54, 371-394. [CrossRef]

128. Kelley, E.S.; Kinney, K. Word Learning and Story Comprehension From Digital Storybooks: Does Interaction Make a Difference? J. Educ. Comput. Res. 2017, 55, 410-428. [CrossRef]

129. Banerjee, S.; Chakravarty, S.; Joshi, I.; Pillai, S. Can Digital Technologies Play a Role in Improving Children's Learning Outcomes in India? J. Dev. Policy Pract. 2018, 3, 55-86. [CrossRef]

130. Müller, A.; Son, J.B.; Nozawa, K.; Dashtestani, R. Learning English Idioms with a Web-Based Educational Game. J. Educ. Comput. Res. 2018, 56, 848-865. [CrossRef]

131. Sadeghi, K.; Dousti, M. The Effect of Length of Exposure to Computer-based Vocabulary Activities on Young Iranian EFL Learners' Vocabulary Gain. Theory Pract. Lang. Stud. 2014, 4. [CrossRef]

132. Wichadee, S.; Pattanapichet, F. Enhancement of performance and motivation through application of digital games in an english language class. Teach. Engl. Technol. 2018, 18, 77-92.

133. Balula, A.; Martins, C.; Costa, M.; Marques, F. MOBILE betting-Learning business english terminology using mall. Teach. Engl. Technol. 2020, 20, 6-22.

134. Kapsalis, G.; Galani, A.; Tzafea, O. Kahoot! As a Formative Assessment Tool in Foreign Language Learning: A Case Study in Greek as an L2. Theory Pract. Lang. Stud. 2020, 10, 1343. [CrossRef]

135. Calvo-Ferrer, J.R. Educational games as stand-alone learning tools and their motivational effect on L2 vocabulary acquisition and perceived learning gains. Br. J. Educ. Technol. 2017, 48, 264-278. [CrossRef]

136. Taguchi, N.; Li, Q.; Tang, X. Learning Chinese Formulaic Expressions in a Scenario-Based Interactive Environment. Foreign Lang. Ann. 2017, 50. [CrossRef]

137. Ibrahim, K. Foreign language practice in simulation video games: An analysis of game-based FL use dynamics. Foreign Lang. Ann. 2019, 52, 335-357. [CrossRef]

138. Müller, A. Improving the identification of medication names by increasing phonological awareness via a language-teaching computer game (Medicina). In Serious Games for Healthcare: Applications and Implications; IGI Global: Hershey, PA, USA, 2013; pp. 283-295.

139. Keller, J.M. Development and use of the ARCS model of instructional design. J. Instr. Dev. 1987, 10, 2-10. [CrossRef]

140. Deterding, S.; Khaled, R.; Nacke, L.; Dixon, D. Gamification: Toward a Definition. In Proceedings of the CHI 2011 Gamification Workshop, Vancouver, BC, Canada, 7-12 May 2011; Association for Computing Machinery: New York, NY, USA, 2011 ; pp. 12-15.

141. Schell, J. The Art of Game Design: A Book of Lenses, 2nd ed.; A K Peters/CRC Press: Boca Raton, FL, USA, 2014.

142. Mora, A.; Riera, D.; González González, C.; Arnedo-Moreno, J. Gamification: A systematic review of design frameworks. J. Comput. High. Educ. 2017, 29, 1-33. [CrossRef]

143. Marczewski, A. Even Ninja Monkeys Like to Play: Unicorn Edition; Gamified: London, UK, 2018. 
144. Tondello, G.F.; Wehbe, R.R.; Diamond, L.; Busch, M.; Marczewski, A.; Nacke, L.E. The Gamification User Types Hexad Scale. In Proceedings of the 2016 Annual Symposium on Computer-Human Interaction in Play, Austin, TX, USA, 16-19 October 2016; Association for Computing Machinery: New York, NY, USA, 2016; pp. 229-243. [CrossRef]

145. Manzano-León, A.; Camacho-Lazarraga, P.; Guerrero-Puerta, M.A.; Guerrero-Puerta, L.; Alias, A.; Trigueros, R.; Aguilar-Parra, J.M. Adaptation and validation of the scale of types of users in gamification with the Spanish adolescent population. Int. $J$. Environ. Res. Public Health 2020, 17, 4157. [CrossRef]

146. Tondello, G.F.; Mora, A.; Marczewski, A.; Nacke, L.E. Empirical validation of the Gamification User Types Hexad scale in English and Spanish. Int. J. -Hum.-Comput. Stud. 2019, 127, 95-111. [CrossRef]

147. Fischer, H.; Heinz, M.; Breitenstein, M. Gamification of Learning Management Systems and User Types in Higher Education. In Proceedings of the 12th European Conference on Game-Based Learning (ECGBL 2018), Sophia Antipolis, France, 4-5 October 2018; Academic Conferences and Publishing Limited: South Oxfordshire, UK, 2018; pp. 91-98.

148. Gil, B.; Cantador, I.; Marczewski, A. Validating gamification mechanics and player types in an e-learning environment. In Design for Teaching and Learning in a Networked World; Springer: Berlin/Heidelberg, Germany, 2015; pp. 568-572.

149. Akgün, Ö.E.; Topal, M. Adaptation of the Gamification User Types Hexad Scale into Turkish. Int. J. Assess. Tools Educ. 2018, 5, 389-402. [CrossRef]

150. Chou, Y. Actionable Gamification: Beyond Points, Badges, and Leaderboards; Packt Publishing: Birmingham, UK, 2019.

151. Mojang Studios. Minecraft; Game [Android, iOS, Windows, Xbox One, Nintendo Switch, PS4, macOS, Fire OS, Gear VR]; Mojang Studios: Stockholm, Sweden, 2009.

152. Saad Mohamed, A.F. Feedback in Computer-Assisted Language Learning: A Meta-Analysis. TESL-EJ 2020, $24, \mathrm{n} 2$.

153. Hamari, J.; Koivisto, J.; Sarsa, H. Does gamification work?-A literature review of empirical studies on gamification. In Proceedings of the 2014 47th Hawaii International Conference on System Sciences, Waikoloa, HI, USA, 6-9 January 2014; pp. 3025-3034.

154. Kiili, K. Digital game-based learning: Towards an experiential gaming model. Internet High. Educ. 2005, 8, 13-24. [CrossRef]

155. Team Bondi. L.A. Noire; Game [PlayStation 4, Xbox One, Xbox 360, Microsoft Windows]; Rockstar Games: New York, NY, USA, 2011.

156. Maxis. The Sims; Game [Microsoft Windows]; Electronic Arts: Redwood City, CA, USA, 2000.

157. Blizzard Entertainment. World of Warcraft; Game [Microsoft Windows]; Blizzard Entertainment: Irvine, CA, USA, 2004.

158. Gravity. Ragnarok Online; Game [Microsoft Windows]; Gravity: Seoul, South Korea, 2002.

159. Sam Barlow. Her Story; Game [Microsoft Windows, iOS, OS X]; Sam Barlow: Brooklyn, NY, USA, 2015.

160. Auray Studios. Phrasal Nerds: Phrasal Verbs; Game [Android, iOS]; Auray Studios: Berlin, Germay, 2014.

161. Kahoot! Kahoot! Game [Online]; Kahoot: Berlin, Germay, 2013.

162. Kartal, G. What's up with WhatsApp? A Critical Analysis of Mobile Instant Messaging Research in Language Learning. Int. J. Contemp. Educ. Res. 2019, 6, 352-365. [CrossRef]

163. Çetinkaya, Ş.E. Bringing Classroom and Outside World Together: Mobile Instant Messaging via WhatsApp@ for Extracurricular Writing. Qual. Rep. 2020, 25, 4319-4351.

164. Shi, Z.; Luo, G.; He, L. Mobile-assisted Language Learning Using WeChat Instant Messaging. Int. J. Emerg. Technol. Learn. 2017, 12, 16-26. [CrossRef] 